\title{
Opthalmomyiasis Externa: Two Cases Identified in a Tertiary Care Centre, North India
}

\author{
Sudhir Singh, Shweta R Sharma*, Umar Farooq, Shewtank Goel and Imran Ahamad \\ Department of Microbiology, Teerthankar Mahaveer Medical College \& Research Centre, India
}

Submission: September 11, 2018; Published: September 24, 2018

*Corresponding author: Shweta R Sharma, Department of Microbiology, Teerthankar Mahaveer Medical College \& Research Centre, Moradabad, India, Email: drshwetamicro@gmail.com

\begin{abstract}
Ophthalmomyiasis or ocular myiasis refers specially to infestation of any anatomic structure of the eye. Cases of Ophthalmomyiasis externa is usually caused by sheep nasal botfly Oestrus ovis. Here we are reporting two cases of opthalmomyiasis externa who presented in our hospital with acute complaints. Both patients were educated, clean and belonged to middle socio-economic strata and none of them were having history of contact with animals like sheep or goats.
\end{abstract}

Keywords: Ophthalmomyiasis; Oestrus ovis; Myiasis

\section{Introduction}

Myiasis is the term used in condition where there is infestation of living and/or dead animal tissue by dipterous fly larvae (maggots). Occurrence and site of invasion of myiasis vary with the sanitary conditions, environmental factors, and presence of devitalised tissue that results from traumatic injury, erosive, ulcerative or haemorrhagic lesions [1]. Ophthalmomyiasis or ocular myiasis refers specially to infestation of any anatomic structure of the eye. Cases of Ophthalmomyiasis externa is usually caused by sheep nasal botfly Oestrus ovis. Globally, this disease has been mostly reported from rural areas and in patients with history of contact with sheep or goats [2]. However, the incidence of this disease is decreasing even in the developing countries because of increased awareness about personal hygiene. Here we are reporting two cases of opthalmomyiasis externa who presented in our hospital with acute complaints. Both patients were educated, clean and belonged to middle socio-economic strata and none of them were having history of contact with animals like sheep or goats.

\section{Case 1}

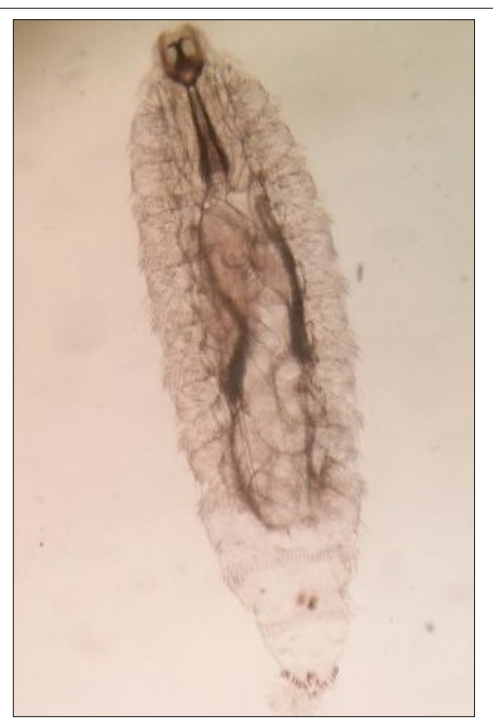

Figure 1: Larvae showing characteristic sharp, dark brown oral hooks connected to the large internal cephalopharyngeal skeleton, body divided into 11 segments covered by tufts of numerous hooks. 
A 28-year-old post graduate student presented to the Ophthalmology-OPD with complaints of severe irritation and discomfort in her left eye associated with pain, itching, watering and foreign body sensation since two days. It was not associated with photophobia or purulent discharge. Patient saw that something is moving in her eye. The patient belonged to middle socio-economic strata and had good personal hygiene. She was a contact lens wearer since 3 years. Patient also gives history of some splash directly into left eye while doing some procedure four days back. On examination, multiple larvae were seen in both upper and lower fornices of left eye which were removed carefully with fine forceps under topical anaesthesia and eye was washed with sterile normal saline. The larvae were sent in normal saline to the department of Parasitology for identification. Larvae measured 1.5-2 X 0.5mm with characteristic sharp, dark brown oral hooks connected to the large internal cephalopharyngeal skeleton. The body was divided into 11 segments, each being covered by tufts of numerous brown hooks with spinose tips on the anterior margin (Figure 1). The larvae were thus identified as Oestrus ovis (sheep nasal botfly) [3]. Topical antibiotic drops (ciprofloxacin) were prescribed to the patient for three days. On follow up eyes were clear, and the patient was relieved from all symptoms. The patient was followed up for a further two weeks, and no complication was noted.

\section{Case 2}

A 24-year-old graduate student presented to the Ophthalmology-OPD with complaints of severe irritation, itching, photophobia and watering in the left eye since yesterday. It was not associated with any purulent discharge. Patient reported that he had a fall of insect in left eye following which he rubbed his eyes and later washed with clean water two days back. On examination, multiple larvae were seen in both upper and lower fornices of left eye which were removed carefully with fine forceps under topical anaesthesia and eye was washed with sterile normal saline. The larvae were sent in normal saline to the department of Parasitology for identification. The larvae were characteristically identified as Oestrus ovis (sheep nasal botfly) as described in the first case. Patient was treated with topical antibiotic drops (ciprofloxacin) and on follow up examination he was completely alright with no further complications.

\section{Discussion}

Myiasis of the face occurs in $1 \%$ of cases. Ocular myiasis being still fewer, is reported here for its rarity [4]. On the basis of structure of eye involved, these can be classified into 3 forms -Ophthalmomyiasis externa (infestation of conjunctiva), Ophthalmomyiasis interna (ocular globe involvement where larvae visualised in subretinal space and in the vitreous cavity) and Orbital Ophthalmomyiasis (invasion of the orbit). Many dipterous flies of the genera Chrysomia (old world screwworm), Cochliomyia (New world screwworm), Oestrus (sheep botfly) and Hypoderma (cattle botfly) have been reported to cause myiasis in human and / or domestic animals [1,4]. Oestrus ovis ophthalmomyiasis is worldwide in distribution while $C$. hominivorax ophthalmomyiasis is limited in distribution to America [5]. Larvae mature within four to seven days, usually in wounds or body orifices. Poor living and hygiene conditions of patients are other contributing factors in causing infection. The compromising of periorbital tissues by surgery, malignancy, ischemia, or infection predisposes the patient to myiasis. Shepherds are at greatest risk for Oestrus ovis infections as it infests sheep. Man is an accidental host. Oestrus ovis female flies are capable of ejecting a jet of larvae while in close proximity to the eye [6]. Thus, fly can hit the eye or larvae can enter eye through the contacts of sheep [7,8]. In our cases, one patient reported about fall of insect in the eye and the clinical symptoms appeared after that. However other patient reported about the use of contact lens and some spillage in the eye. In this case we presumed that either the spillage liquid was contamination, or the lens solution is contaminated with larvae.

The clinical presentation of Ophthalmomyiasis is similar to viral or allergic conjunctivitis, marked by pain, burning, itching, redness, and watering in the affected eyes. Many patients report having had an insect buzzing around their face or striking them in the eye immediately prior to the onset of symptoms. If cases are neglected in early stages, maggots may cause direct mechanical damage and lead to haemorrhage, ulceration or even potential invasion. In extreme cases the larvae may penetrate the mucosal sinus causing swelling, pain, frontal headache and may invade the ocular globe leading to retinal damage and blindness. Internal ophthalmomyiasis can produce vitreous hemorrhage, retinal detachment, endophthalmitis, hypopigmented linear and subretinal tracts $[9,10]$.

Mostly, the larvae are visible on examining the eye and can be seen travelling through the cornea or in the fornices. Sometimes, careful search is required if larvae are deep in the fornices. Larvae need to be removed carefully from the eye with the help of fine forceps. Anaesthetic drops help in immobilising the larvae during removal. Antibiotic ointments also help to suffocate the larvae, thereby facilitating removal. Local antibiotics and topical corticosteroids further prevent secondary bacterial infection and reduce inflammation. Treatment strategies in cases of internal ophthalmomyiasis ranges from iridectomy, vitrectomy, retinotomy and laser photocoagulation as per the case presentation [11]. Follow-up examinations are necessary in such cases to rule out complications or the existence of additional larvae. In our cases both the patients reported early and hence larvae were removed and no further complications were noted on follow up examination.

\section{Conclusion}

To conclude, medical personnel should be aware of ophthalmomyiasis to make timely diagnosis and to consider it in the differential diagnosis of acute conjunctivitis. Early diagnosis and prompt treatment not only reduce morbidity and the duration of discomfort, but also reduces the potential complication of opthalmomyiasis interna. 


\section{References}

1. Pandey TR, Shrestha GB, Kharel R, Shah DN (2016) A Case of Orbital Myiasis in Recurrent Eyelid Basal Cell Carcinoma Invasive into the Orbit. Case Reports in Ophthalmological Medicine 2016(2904346): 4.

2. Misra S, Misra N, Reddy B (2008) External ophthalmomyiasis by Oestrus ovis: an unknown endemic eye disease in rural parts of central India. Trop Doct 38: 120-122.

3. Khurana S, Biswal M, Bhatti HS, Pandav SS, Gupta A, et al. (2010) Ophthalmomyiasis: Three cases from North India. Indian J Med Microbiol 28(3): 257-261.

4. Tomy RM, Prabhu PB (2013) Ophthalmomyiasis externa by Musca domestica in a case of orbital metastasis. Indian J Ophthalmol 61(11): 671-673.

5. Lagacé-Wiens PR, Dookeran R, Skinner S, Leicht R, Colwell DD, et al. (2008) Human ophthalmomyiasis interna caused by Hypoderma tarandi, Northern Canada. Emerg Infect Dis 14(1): 64-66.

6. Sigauke E, Beebe WE, Gander RM, Cavuoti D, Southern PM (2003) Case
Report: Ophthalmomyiasis Externa in Dallas County, Texas. Am.J. Trop Med Hyg 68(1): 46-47.

7. Thakur K, Singh G, Chauhan S, Sood A (2009) Vidi, vini, vinci: External ophthalmomyiasis infection that occurred and was diagnosed and treated in a single day: a rare case report. Oman J Ophthamol 2(3): 130-132.

8. Smillie I, Gubbi PK, Cocks HC (2010) Nasal and ophthalmomyiasis: case report. J Laryngol Otol 124(8): 934-935.

9. Sreejith RS, Reddy AK, Ganeshpuri SS, Garg P (2010) Oestrus ovis ophthalmomyiasis with keratitis. Indian J Med Microbiol 28(4): 399 402.

10. Jenzeri S, Ammari W, Attia S, Zaouali S, Babba H, et al. (2009) External ophthalmomyiasis manifesting with keratouveitis. Int Ophthalmol 29(6): 533-535.

11. Huynh N, Dolan B, Lee S, Whitcher JP, Stanley J (2005) Management of screwworm ophthalmomyiasis externa. Br J Ophthalmol 89(10): 1377- 1378 .
This work is licensed under Creative Commons Attribution 4.0 License DOI: 10.19080/JOJCS.2018.08.555744

\section{Your next submission with Juniper Publishers will reach you the below assets}

- Quality Editorial service

- Swift Peer Review

- Reprints availability

- E-prints Service

- Manuscript Podcast for convenient understanding

- Global attainment for your research

- Manuscript accessibility in different formats

( Pdf, E-pub, Full Text, Audio)

- Unceasing customer service

Track the below URL for one-step submission https://juniperpublishers.com/online-submission.php 